\title{
ANALISIS FAKTOR MOTIVASI JATI DIRI MUSLIM MELAKSANAKAN HAJI
} DAN UMRAH

\section{(Studi Pada Masyarakat Desa Riak Siabun Dusun Parit Tiga Kecamatan Sukaraja Kabupaten Seluma)}

\author{
Miti Yarmunida, Evan Stiawan*, Makmur** \\ Program Studi Manajemen Haji dan Umrah FEBI IAIN Bengkulu \\ E-Mail: mhufebi.ainbengkulu@gmail.com
}

\begin{abstract}
Population that is quite high in making Indonesian society equitable is busy carrying out the Hajj and Umrah. This is reflected in the waiting time queuing for the Hajj in Indonesia, which ranges from 10-17 years. The data shows that there is a lot of enthusiasm from the people in carrying out the Hajj, but to fill the waiting time, there are many people who are doing umrah. This study aims to determine the motivational factors of the community to carry out the Hajj and Umrah. The study design study uses factor analysis methods through the Barlett test of sphericity test, Kaiser Mesyer Olkin (KMO), and Measure Sampling Adequacy (MSA). Individual factors, namely age and education cannot be a significant factor in influencing the pilgrimage and umrah.
\end{abstract}

Keywords: Hajj, Umrah, Motivation, Identity

\section{LATAR BELAKANG}

Haji dan umroh secara harfiah berarti "menuju, mengunjungi, terus menerus pergi dan mengunjungi tempat yang penting dan terhormat."Sebagai istilah Islam haji berarti ibadah yang dilakukan di bulan Zulhijah tahun Hijriyah dengan melakukan beberapa tugas keagamaan sesuai dengan kondisi mereka dan metode dengan benar di Ka'bah, Arafah, Muzdalifa dan Mina.

Ibadah haji merupakan rukun Islam kelima yang wajib dilaksanakan oleh setiap orang Islam yang memenuhi syarat istitaah, baik secara finansial, fisik, maupun mental.
Negara bertanggung jawab atas penyelenggaraan ibadah haji sebagaimana yang diamanatkan dalam Pasal 29 Ayat (2) Undang-Undang Dasar Negara Republik Indonesia Tahun 1945, yang menyatakan bahwa Negara menjamin kemerdekaan tiaptiap penduduk untuk memeluk agamanya masing-masing dan untuk beribadat menurut agama dan kepercayaannnya itu. Indonesia sebagai salah satu negara yang memiliki jumlah penduduk beragama Islam terbesar di dunia, melakukan penyelenggaraan ibadah haji setiap tahunnya. Saat ini dasar dan payung hukum pelaksanaan penyelenggaraan ibadah haji berdasarkan pada Undang- 
undang Nomor 13 Tahun 2008 Tentang Penyelenggaraan Ibadah Haji. Dalam Undang-Undang Nomor 13 Tahun 2008 tentang Penyelenggaraan Ibadah Haji, mengatur mengenai rangkaian kegiatan pengelolaan pelaksanaan ibadah haji yang meliputi pembinaan, pelayanan, dan perlindungan jemaah haji. Adapun tujuan Penyelenggaraan ibadah haji yaitu untuk memberikan pembinaan, pelayanan, dan perlindungan yang sebaik-baiknya bagi jemaah haji sehingga jemaah haji dapat menunaikan ibadahnya sesuai dengan ketentuan ajaran agama Islam. Penyelenggaraan ibadah haji dilaksanakan berdasarkan asas keadilan, profesionalitas, dan akuntabilitas dengan prinsip nirlaba.

Allah SWT memerintahkan haji dalam ayat ke-97 Surah al Al-Imran: "Disana terdapat tanda tanda yang jelas (petunjuk Allah), diantaranya maqam tempat Ibrahim berdiri untuk berdoa, dan siapa saja yang memasukinya maka amanlah dia. Dan ziarah ke Baitullah adalah kewajiban kepada Allah bagi umat manusia, bagi orang yang dapat menemukan jalan ke sana. Adapun orang yang mengingkari (kewajiban) haji, ketahuilah bahwa Allah Maha Kaya (tidak memerlukan sesuatu dari semua makhluk) "(QS. al Al-Imran I, 97).

"Sempurnakan ibadah haji dan umrah karena Allah." (QS. al Baqarah, 196) "Wahai manusia! Allah SWT telah menetapkan kewajiban ibadah haji. Bersegeralah untuk melakukan ibadah haji." (Muslim)

Haji adalah salah satu rukun Islam. Jadi, itu adalah perintah Allah (swt) yang fardhu seperti sholat dan puasa. Diriwayatkan oleh 'Abdullah bin' Umar bahwa Rasulullah (saw) bersabda: "Kekuatan islam ditopang oleh lima (pilar), bersaksi bahwa tidak ada Tuhan selain Allah, bahwa Muhammad adalah hamba dan utusan-Nya, dan melaksanakan sholat, membayar Zakat, Ziarah ke Rumah Allah (Ka'bah) dan puasa Ramadhan. "(Sahih Muslim, Buku 1, Hadis 20)

Kunjungan ke Ka'bah adalah khusus bagi umat Islam. Dalam agama Kristen dan Yudaisme tidak ada kewajiban haji sesuai dengan doktrin Islam. "Barang siapa yang memiliki cukup makanan untuk perjalanan, alat transportasi untuk mencapai ke Mekah, namun tidak melakukan haji, kemudian ia mati, ia maka akan mati sebagai seorang Yahudi atau Kristen" (At-Tirmidzi, AlBazzar)

Haji, selain merupakan kewajiban, adalah cara pendidikan juga. Haji menetapkan akhlak yang baik dan menghasilkan manfaat sosial banyak yang membawa banyak kebaikan untuk individu dan masyarakat Muslim.

Seorang Haji menghadapi banyak kesulitan, kesukaran dan situasi sulit selama periode persiapan, perjalanan dan ritual 
selama haji yang mengajarkan dia untuk bersabar dan tunduk, lembut dan permisif dan mengajarkan bagaimana mengontrol emosinya dan tetap tenang. Haji dan umroh

dapat persaudaraan

memperkuat

universal

perasaan

memanifestasikan bahwa Islam adalah agama persatuan dan solidaritas. Haji menghapus segala macam perbedaan dan memberikan kesatuan umat Islam. Dua juta orang dari ratusan negara yang berbeda dan bangsa yang berbeda, warna yang berbeda dan budaya yang berbeda berkumpul di tempat yang sama untuk tujuan yang sama, mereka mengenakan pakaian yang sama dan menghadap ke Kiblat yang sama.

Mereka berbagi perasaan yang sama dan tindakan yang sama. Mereka menyebut Tuhan yang unik yang sama dan mengikuti langkah-langkah Nabi yang sama (saw). Tidak peduli mereka kaya atau miskin mereka sama dalam kewajiban dan hak. Seluruhnya ini membuat Muslim menyadari bahwa mereka sebenarnya hanyalah saudara satu sama lain atas nama Islam. Jadi, haji membentuk persaudaraan yang tulus di kalangan umat Islam dan jelas memanifestasikan bahwa Islam adalah agama persatuan dan solidaritas.

Masyarakat Indonesia yang memiliki populasi yang cukup tinggi dalam membuat masyarakat Indonesia beramai ramai melaksanakan ibadah haji dan umrah. Hal ini tercermin pada waktu tunggu antri untuk ibadah haji di Indonesia yaitu berkisar waktu 10-17 Tahun. Data tersebut menunjukan bahwa sangat banyak sekali antusiasmen warga dalam melaksanakamn ibadah haji, akan tetapi untuk mengisi waktu tunggu tersebut yang cukup lama banyak masyarakat yang melakukan ibadah umrah. Data kedutaan arab Saudi pada tahun 2016 mengeluarkan sebanyak $6,393,464$ visa umrah hal ini cenderung meningkat setiap tahunnya.

Penelitian ini dikaji berdasarkan rumusan masalah yaitu masih kurangnya motivasi dalam melaksanakan haji dan umroh, kurangnya pengetahuan secara fiqih mengenai haji dan umroh, dan tidak adanya pengetahuan mengenai haji dan umroh. Penelitian ini bertujuan mengetahui tingkat motivasi masyarakat dan mengetahui faktorfaktor yang mempengaruhi motivasi masyarakat dalam ibadah haji dan umrah. Oleh karena itu penelitian ini memberikan mengukur bagaimana tingkat motivasi masyarakat yang akan melaksanakan ibadah haji dan umrah lalu faktor-faktor lain yang mempengaruhi.

\section{LITERATUR REVIEW}

Motivasi dapat diartikan sebagai kekuatan (energi) seseorang yang dapat menimbulkan tingkat persistensi dan entusiasmenya dalam melaksanakan suatu kegiatan, baik yang bersumber dari dalam 
diri individu itu sendiri (motivasi intrinsik) maupun dari luar individu (motivasi ekstrinsik). Seberapa kuat motivasi yang dimiliki individu akan banyak menentukan terhadap kualitas perilaku yang ditampilkannya, baik dalam konteks belajar, bekerja maupun dalam kehidupan lainnya.

Dalam Teori motivasi yang dikembangkan oleh Abraham H. Maslow pada intinya berkisar pada pendapat mengenai konsep motivasi manusia dan mempunyai lima hierarki kebutuhan ${ }^{1}$, yaitu: Pertama yaitu kebutuhan yang bersifat fisiologis (lahiriyah) Manifestasi kebutuhan ini terlihat dalam tiga hal pokok, sandang, pangan dan papan. Teori ini bisa dikatakan sebagai suatu hal yang memang mendasari seseorang untuk melakukan sesuatu demi mendapatkan kebutuhan ini. Example, Bagi karyawan, kebutuhan akan gaji, uang lembur, rumah, kendaraan dll, yang merupakan kebutuhan pokok, menjadi motif dasar dari karyawan itu sendiri mau bekerja, menjadi efektif dan dapat memberikan produktivitas yang tinggi bagi organisasi.

Kedua yaitu kebutuhan keamanan dan ke-selamatan kerja (Safety Needs), kebutuhan ini mengarah kepada rasa keamanan, ketentraman dan jaminan seseorang dalam kedudukannya, jabatan-nya,

\footnotetext{
${ }^{1}$ Kotler, Philip, dan Kevin Lane Keller. 2009. Manajemen Pemasaran, Hlm. 102
}

wewenangnya dan tanggung jawabnya sebagai karyawan. Dia dapat bekerja dengan antusias dan penuh produktivitas bila dirasakan adanya jaminan formal atas kedudukan dan wewenangnya. Example, kebutuhan ini lebih dibutuhkan bagi seseorang yang bekerja dalam organisasi yang menghasilkan produk berupa barang, tidak hanya keselamatan dan keamanan dalam kedudukan, tetapi keamanan dan keselamatan pekerjaan itu sendiri, seperti para buruh yang bekerja pada pabrik yang mengolah bahan kimia, mereka butuh rasa keamanan yang tinggi, buruh bangunan.

Ketiga yaitu kebutuhan sosial (Social Needs), kebutuhan akan kasih sayang dan bersahabat (kerjasama) dalam kelompok kerja atau antar kelompok. Kebutuhan akan diikutsertakan, mening-katkan relasi dengan pihak-pihak yang diperlukan dan tumbuhnya rasa kebersamaan termasuk adanya sense of belonging dalam organisasi. Example, biasa lebih diperlukan oleh karyawan yang diharuskan bekerja dibalik meja atau computer, terutama seperti mereka yang bekerja sebagai administrator dalam suatu jejaring sosial, meskipun mereka bisa bersosialisasi lewat dunia maya, tetap saja mereka membutuhkan kehadiran orangorang sekitar yang dapat diajak kerja sama dan bisa diajak berbicara sambil menunjukkan emosinya. 
Keempat yaitu kebutuhan akan prestasi (Esteem Needs), kebutuhan akan kedudukan dan promosi dibidang kepegawaian. Kebutuhan akan simbol-simbol dalam statusnya seseorang serta prestise yang ditampilkannya. Example, setiap karyawan memiliki prestasi masing-masing, dalam hal itu mereka berkompetisi dalam menyelesaikan tugas sebaik-baiknya, setelah pencapaian usaha mereka dinilai baik oleh organisasi dan atasan, biasanya mereka diberikan piagam, atau suatu emblem yang dapaut menunjukkan bahwa ia adalah seorang yang berhasil dalam bidangnya sesuai dengan yang diharapkan organisasi. Kebutuhan akan hal tersebut memancing mereka untuk terus giat menapaki bidangnya masing-masing.

Kelima yaitu kebutuhan Akutualisasi Diri (Self Actualization), setiap orang ingin mengembangkan kapasitas kerjanya dengan baik. Hal ini merupakan kebutuhan untuk mewujudkan segala kemampuan (kebolehannya) dan seringkali nampak pada hal-hal yang sesuai untuk mencapai citra dan cita diri seseorang. Dalam motivasi kerja pada tingkat ini diperlukan kemampuan manajemen untuk dapat mensinkronisasikan antara cita diri dan cita organisasi untuk dapat melahirkan hasil produktivitas organisasi yang lebih tinggi.

Teori Maslow tentang motivasi secara mutlak menunjukkan perwujudan diri sebagai pemenuhan (pemuasan) kebutuhan yang bercirikan pertumbuhan dan pengembangan individu. Perilaku yang ditimbulkannya dapat dimotivasikan oleh manajer dan diarahkan sebagai subjek-subjek yang berperan. Dorongan yang dirangsang ataupun tidak, harus tumbuh sebagai subjek yang memenuhi kebutuhannya masingmasing yang harus dicapainya dan sekaligus selaku subjek yang mencapai hasil untuk sasaran-sasaran organisasi.

Kebutuhan-kebutuhan yang disebut pertama (fisiologis) dan kedua (keamanan) kadang-kadang diklasifikasikan dengan cara lain, misalnya dengan menggolongkannya sebagai kebutuhan primer, sedangkan yang lainnya dikenal pula dengan klasifikasi kebutuhan sekunder. Terlepas dari cara membuat klasifikasi kebutuhan manusia itu, yang jelas adalah bahwa sifat, jenis dan intensitas kebutuhan manusia berbeda satu orang dengan yang lainnya karena manusia merupakan individu yang unik. Juga jelas bahwa kebutuhan manusia itu tidak hanya bersifat materi, akan tetapi bersifat psikologikal, mental, intelektual dan bahkan juga spiritual.

Minat adalah suatu dorongan maupun keinginan pada diri seseorang terhadap suatu objek tertentu. Minat bersifat individu (pribadi) jadi setiap orang memiliki minat ataupun keinginan yang berbeda satu sama lain. Sedangkan masyarakat adalah sekumpulan orang yang saling berinteraksi satu sama lain dalam satu komunitas yang 
teratur. Jadi, minat masyarakat adalah suatu dorongan keinginan sekelompok orang yang saling berinteraksi terhadap suatu objek tertentu. Dalam memilih biro perjalanan umrah terdapat beberapa factor yang dapat dianalisis yakni : 1. Harga Harga adalah sesuatu nominal uang yang harus diberikan oleh pembeli untuk memperoleh suatu produk. Harga juga berperan penting dalam kelangsungan hidup suatu perusahaan yakni untuk mendapatkan suatu keuntungan dari produk yang telah dijual. Harga merupakan factor yang paling utama dalam menentukan keputusan pembelian. Kementrian Agama telah menetapkan standart harga dalam menunaikan ibadah umrah. Sehingga masyarakat harusnya menjadikan standart harga tersebut sebagai acuan untuk memilih suatu biro perjalanan haji dan umroh ketika akan menunaikan ibadah umrah. Apabila harga yang dipatok suatu biro perjalanan haji dan umrah jauh dari harga standrat yang telah ditetapkan Kementrian Agama maka masyarakat seharusnya bertanyatanya, tidak lantas langsung tergiur dengan harga yang murah atau jauh dibawah standart Kementrian Agama. Pasalnya dengan harga yang begitu murah bagaimana suatu biro perjalanan haji dan umroh dapat memberangkatkan Jemaah ketanah suci.

Pelayanan yaitu suatu kegiatan yang ditawarkan kepada pelanggan maupun konsumen yang akan dilayani. Menurut kamus bahasa Indonesia pelayanan berarti suatu kegiatan melayani kebutuhan orang lain. Menurut plilip kotler, pelayanan adalah suatu aktifitas yang bermanfaat yang diberikan oleh satu pihak kepada pihak lain untuk dapat memuaskan kebutuhan dan keinginan yang pada dasarnya bersifat berwujud dan tidak akan menimbulkan kepemilikan apapun kepada yang menerima. Pelayanan yang dilakukan secara baik kepada orang lain ataupun konsumen dapat menunjukkan perasaan senang pada konsumen. Memuaskan konsumen berarti memuaskan kebutuhan-kebutuhan mereka. Sehingga kepuasan pelanggan adalah hal yang paling penting bagi suatu produsen baik produk maupun jasa. Bentuk pelayanan yang dilakukan oleh biro perjalanan umroh dan haji kepada jemaahnya misalnya, pendaftaran, pembinaan, handling dibandara (menuntun jamaah saat keberangkatan dibandara), perjalanan selama melaksanakan ibadah, pemulangan, pembinaan pasca umroh. 3. Kepercayaan Salah satu factor yang paling penting dalam mempengaruhi keputusan konsumen dalam pembelian suatu produk atau jasa ialah kepercayaan. Karena kepercayaan ialah keinginan seseorang dimana ia memeliki keyakinan untuk bertumpu pada orang lain yang ia yakini. Ketika seseorang mengambil keputusan, ia akan lebih condong memilih keputusan 
berdasarkan pilihan orang-orang yang lebih dapat dipercaya dari pada yang kurang dipercayai. Kepercayaan dapat diperoleh melalui informasi dari seseorang ataupun beberapa orang (kelompok) yang dekat dengan kita. Misalnya saja Keluarga, Sahabat, Tetangga. Informasi yang berasal dari keluarga dapat memberikan kita keyakinan untuk memutuskan suatu keputusan. Informasi yang berasal dari keluarga berperan penting dalam pengambilan suatu keputusan, sehingga seseorang akan lebih cenderung mempercayai informasi/opini yang berasal dari keluarga. Tidak hanya berasal dari keluarga, tetangga dapat pula mempengaruhi konsumen dalam pengambilan keputusan pembelian.

Tetangga yang sudah menunaikan ibadah umrah dapat memberikan informasiinformasi mengenai suatu biro perjalanan haji dan umrah. Tidak hanya tetangga, melalui teman dekat ataupun sahabat yang telah berpengalamanpun dapat memberikan informasi-informasi dalam pengambilan keputusan. Sehingga referensi dapat mempengaruhi konsumen dalam pengambilan keputusan pembelian jasa pada biro-biro perjalanan haji dan umrah. Penipuan berkedok umroh adalah suatu kegiatan meperkaya dirisendiri dengan cara memakai tipu muslihat kepada calon jamaah umroh. Dari kebanyakan kasus diindonesia penipuan berkedok umroh mislanya saja First Travel yang memberikan harga jauh dibawah standart yang telah di tetapkan oleh kemenag, sehingga banyak konsumen yang tergiur dengan tawaran dari first travel. Tidak hanya itu first travel juga menggaet bintang papan atas syahrini untuk mempromosikan produknya sehingga memberi keyakinan pada masyarakat mengenai produk first travel. First travel adalah Perusahaan bidang jasa yang telah lama berdiri dan sudah banyak cabangnya diindonesia,yang pada awalnya bukan merupakan perusahaan penipu namun karena gaya hidup pemilik yang mewah membuat calon jamaah umroh tidak berangkat ketanah suci.

Motivasi dapat berupa motivasi intrinsic dan ekstrinsic. Motivasi yang bersifat intinsik adalah manakala sifat pekerjaan itu sendiri yang membuat seorang termotivasi, orang tersebut mendapat kepuasan dengan melakukan pekerjaan tersebut bukan karena rangsangan lain seperti status ataupun uang atau bisa juga dikatakan seorang melakukan hobbynya. Sedangkan motivasi ekstrinsik adalah manakala elemen elemen diluar pekerjaan yang melekat di pekerjaan tersebut menjadi faktor utama yang membuat seorang termotivasi seperti status ataupun kompensasi.

$$
\text { Banyak teori motivasi yang }
$$
dikemukakan oleh para ahli yang 
dimaksudkan untuk memberikan uraian yang menuju pada apa sebenarnya manusia dan manusia akan dapat menjadi seperti apa. Landy dan Becker membuat pengelompokan pendekatan teori motivasi ini menjadi 5 kategori yaitu teori kebutuhan,teori penguatan,teori keadilan,teori harapan,teori penetapan sasaran.

Menurut Herzberg (1966), ada dua jenis faktor yang mendorong seseorang untuk berusaha mencapai kepuasan dan menjauhkan diri dari ketidakpuasan. Dua faktor itu disebutnya faktorhigiene (faktor ekstrinsik) dan faktor motivator (faktor intrinsik). Faktor higiene memotivasi seseorang untuk keluar dari ketidakpuasan, termasuk didalamnya adalah hubungan antar manusia, imbalan, kondisi lingkungan, dan sebagainya (faktor ekstrinsik), sedangkan faktor motivator memotivasi seseorang untuk berusaha mencapai kepuasan, yang termasuk didalamnya adalah achievement, pengakuan, kemajuan tingkat kehidupan, dsb (faktor intrinsik).

Teori dari Vroom (1964) tentang cognitive theory of motivation menjelaskan mengapa seseorang tidak akan melakukan sesuatu yang ia yakini ia tidak dapat melakukannya, sekalipun hasil dari pekerjaan itu sangat dapat ia inginkan. Menurut Vroom, tinggi rendahnya motivasi seseorang ditentukan oleh tiga komponen, yaitu: • Ekspektasi (harapan) keberhasilan pada suatu tugas, Instrumentalis, yaitu penilaian tentang apa yang akan terjadi jika berhasil dalam melakukan suatu tugas (keberhasilan tugas untuk mendapatkan outcome tertentu)., Valensi, yaitu respon terhadap outcome seperti perasaan posistif, netral, atau negatif. Motivasi tinggi jika usaha menghasilkan sesuatu yang melebihi harapanMotivasi rendah jika usahanya menghasilkan kurang dari yang diharapkan.

Clayton Alderfer mengetengahkan teori motivasi ERG yang didasarkan pada kebutuhan manusia akan keberadaan (exsistence), hubungan (relatedness), dan pertumbuhan (growth). Teori ini sedikit berbeda dengan teori maslow. Disini Alfeder mngemukakan bahwa jika kebutuhan yang lebih tinggi tidak atau belum dapat dipenuhi maka manusia akan kembali pada gerakk yang fleksibel dari pemenuhan kebutuhan dari waktu kewaktu dan dari situasi ke situasi.

Asal mula arti haji menurut lughah atau arti bahasa (etimologi) adalah "al-qashdu" atau "menyengaja". Sedangkan arti haji dilihat dari segi istilah (terminology) berarti bersengaja mendatangi Baitullah (ka'bah) untuk melakukan beberapa amal ibadah dengan tata cara yang tertentu dan dilaksanakan pada waktu tertentu pula, menurut syarat-syarat yang ditentukan oleh syara', semata-mata mencari ridho Allah. 
Adapun umrah menurut bahasa untuk menyelesaikan manasik haji. bermakna 'ziarah'. Sedangkan menurut (Pedoman Haji. 1998:2) syara' umrah ialah menziarahi ka'bah, melakukan tawaf di sekelilingnya, bersa'i antara Shafa dan Marwah dan mencukur atau menggunting rambut dengan cara tertentu dan dapat dilaksanakan setiap waktu.

Allah SWT telah menjadikan baitullah suatu tempat yang dituju manusia pada setiap tahun. Allah SWT berfirman :

وَإِدْ جَعَنَا البَيَتَ مَتَابَهُ لِلنَّاس

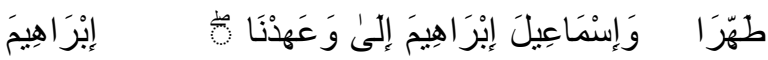

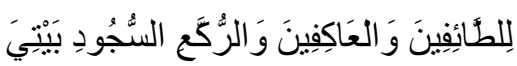

"Dan (ingatlah), ketika Kami menjadikan rumah itu (Baitullah) tempat berkumpul bagi manusia dan tempat yang aman. Dan jadikanlah sebahagian maqam Ibrahim tempat shalat. Dan telah Kami perintahkan kepada Ibrahim dan Ismail: "Bersihkanlah rumah-Ku untuk orang-orang yang thawaf, yang i'tikaf, yang ruku' dan yang sujud". (Al-baqarah :125)

Baitullah adalah suatu tempat yang didatangi manusia pada setiap tahun. Lazimnya mereka yang sudah pernah mengunjungi Baitullah, timbul keinginannya untuk kembali lagi yang kedua kalinya. Maka makna Hajjul baiti menurut syara' ialah : mengunjungi baitullah dengan sifat yang tertentu, di waktu yang tertentu, disertai dengan perbuatan-perbuatan yang tertentu pula. Para ulama telah mengkhususkan kalimat haji untuk mengunjungi ka'bah,

\section{Dasar Hukum Perintah Haji dan Umroh}

Seperti di ketahui, dalam setiap aktivitas ibadah, ada hal-hal yang bersifat fardhu, wajib, sunnah, dan makruh, di samping ada juga mubah (boleh-boleh saja di kerjakan) dan haram. Dalam ibadah haji, fardhu adalah sesuatu yang apabila tidak dikerjakan sesuai ketentuannya, maka ibadah haji tidak sah ; seperti tidak melakukan wukuf di 'Arafah. Wajib dalam ibadah haji atau umrah adalah sesuatu yang jika diabaikan secara keseluruhan, atau tidak memenuhi syaratnya maka haji atau umrah tetap sah, tetapi orang yang bersangkutan harus melaksanakan sanksi yang telah ditetapkan. Misalnya, kewajiban melempar jumroh, bila ia diabaikan, maka ia harus diganti dengan membayar dam (denda). Sesuatu yang sunnah bila dilakukan, atau sesuatu yang makruh, jika ditinggalkan dapat mendukung kesempurnaan ibadah haji dan umrah. Sedang sesuatu yang mubah, tidak berdampak apa pun terhadap ibadah. (Mizan. $2000: 157-158)$

\section{Rukun-rukun Ibadah Haji dan Umrah}

Rukun haji dan umrah merupakan ketentuan-ketentuan/perbuatan-perbuatan yang wajib dikerjakan dalam ibadah haji apabila ditinggalkan, meskipun hanya salah satunya, ibadah haji atau umrahnya itu tidak 
sah. Adapun rukun-rukun haji dan umrah itu adalah sebagai berikut :

a) Ihram

Melaksanakan ihram disertai dengan niat ibadah haji dengan memakai pakaian ihram.Pakaian ihram untuk pria terdiri dari dua helai kain putih yang tak terjahit dan tidak bersambung semacam sarung. Dipakai satu helai untuk selendang panjang serta satu helai lainnya untuk kain panjang yang dililitkan sebagai penutup aurat. Sedangkan pakaian ihram untuk kaum wanita adalah berpakaian yang menutup aurat seperti halnya pakaian biasa (pakaian berjahit) dengan muka dan telapak tangan tetap terbuka.

b) Wukuf di Padang Arafah

Yakni menetap di Arafah, setelah condongnya matahari (ke arah Barat) jatuh pada hari ke-9 bulan dzulhijjah sampai terbit fajar pada hari penyembelihan kurban yakni tanggal 10 dzulhijjah.

c) Thawaf

Yang dimaksud dengan Thawaf adalah mengelilingi ka'bah sebayak tujuh kali, dimulai dari tempat hajar aswad (batu hitam) tepat pada garis lantai yang berwarna coklat, dengan posisi ka'bah berada di sebelah kiri dirinya (kebalikan arah jarum jam). (kumpulanmakalahpai haji)

d) Sa'i antara Shafa dan Marwah

Sai adalah lari-lari kecil sebayak tujuh kali dimulai dari bukit Shafa dan berakhir di bukit Marwah yang jaraknya sekitar 400 meter.Sai dilakukan untuk melestarikan pengalaman Hajar, ibunda nabi Ismail yang mondar-mandir saat ia mencari air untuk dirinya dan putranya, karena usaha dan tawakalnya kepada Allah, akhirnya Allah memberinya nikmat berupa mengalirnya mata air zam-zam.

e) Tahallul

Tahallul adalah menghalalkan pada dirinya apa yang sebelumnya diharamkan bagi dirinya karena sedang ihram. Tahallul ditandai dengan memotong rambut kepala beberapa helai atau mencukurnya sampai habis (lebih afdol)

\section{f)Tertib Berurutan}

Sedangkan Rukun dalam umrah sama dengan haji yang membedakan adalah dalam umrah tidak terdapat wukuf.

\section{METODOLOGI PENELITIAN}

Populasi dalam penelitian ini jumlahnya diketahui yaitu seluruh masyarakat Kbaupaten Seluma lebih kurang 184,913 penduduk. Penentukan sampel dari populasi digunakan acuan tabel yang dikembangkan para ahli salah satu nya adalah Menurut Hair, et al. Penelitian jumlah sampel minimum 50 orang dari masingmasing kelompok ${ }^{2}$. Jadi pada penelitian ini, jumlah sampel dalam peneltiaan ini

${ }^{2}$ Hair, J.F.Jr., Anderson, R.E., Tatham, R.L., \& Black, W.C. (1998), Multivariate Data Analysis $5^{\text {th }}$ Ed. Hlm. 281 
ditetapkan 100 orang masing-masing. Status sampel adalah penduduk di Dusun Parit Tiga Desa Riak Siabun.

Jenis penelitian ini adalah penelitian kausal yang bertujuan untuk menentukan faktor faktor yang mempengaruhi masyarakat dalam melaksankan Ibadah Haji dan Umrah. Dalam menganalisis data penelitian, seringkali peneliti mengalami kesulitan di dalam mendeskripsikan hubungan data yang jumlahnya sangat besar, yang digunakan untuk mengidentifikasi masalah, kesulitan tersebut dapat diatasi dengan menggunakan analisis faktor. Analisis faktor dapat mengungkapkan karakteristik tersamar yang dimiliki oleh setiap unit observasi dari sejumlah besar dan maupun setiap sekumpulan variabel. Karakteristik tersamar tersebut berupa besarnya pengaruh setiap faktor dalam suatu dimensi baru yang disebut faktor.

Barlett test of sphericity dilakukan untuk menguji apakah ada korelasi diantara variabel-variabel. Kaiser Mesyer Olkin (KMO) digunakan untuk mengukur kecukupan pengambilan sampel. Measure Sampling Adequacy (MSA) digunakan untuk memperhitungkan kecukupan penggunaan analisis faktor. Nilai KMO yang kecil memperlihatkan bahwa analisis faktor tidak dapat digunakan, karena korelasi antara pasangan-pasangan variabel tidak dapat dijelaskan oleh variabel-variabel lainnya. ${ }^{3}$

Bila nilai KMO dibawah 0,5 maka analisis faktor tidak dapat digunakan atau diterima. Sedangkan nilai KMO yang dapat diterima adalah nilai di atas 0,5 yaitu 0,6 hingga 0,9. Nilai KMO 0,9 menunjukkan harga yang sangat memuaskan, sedangkan nilai KMO dibawah 0,5 maka analisis faktor tidak dapat diterima. ${ }^{4}$ Definisi Operasional variabel motivasi mengacu pada indikator dari referensi Kottler dan keller. Indikator tersebut dijelaskan oleh Kottler dan keller ada 4 varibel yang terdapat pada masingmasing indikator. Operasionalisasi dari indikator tersebut tercemin pada 17 Pertanyaan. Penelitian menyesuaikan pada konteks yang akan diteliti, maka terdapat keseluruh pertanyaan tersebut digunakan semua dalam penelitian ini.

\section{HASIL PENELITIAN DAN PEMBAHASAN}

Berdasarkan hasil uji analisis data menggunakan analisis faktor, mengidentifiaksi menggunakan alat analisis faktor. Nilai yang ditunjukan adalah nilai MSA dengan standar nilai $>0,5$. Hasil dari uji statistik yaitu dapat ditunjukan sebagai tabel berikut:

\footnotetext{
${ }^{3}$ Bandalos, D.L. (1993). Factors influencing the cross-validation of confirmatory factor analysis models. Hlm 76

${ }^{4}$ Malhotra, N.K. (2004),Marketing Research: An Applied Orientation, Hlm, 89
} 
Tabel Hasil Uji Analisis Faktor

\begin{tabular}{|c|c|c|c|c|c|c|}
\hline Sub variabel & $\begin{array}{c}\text { Standar } \\
\text { Nilai } \\
\text { KMO }\end{array}$ & $\begin{array}{l}\text { Nilai } \\
\text { KMO }\end{array}$ & Indikator & $\begin{array}{c}\text { Standar } \\
\text { Nilai } \\
\text { MSA }\end{array}$ & $\begin{array}{l}\text { Nilai } \\
\text { MSA }\end{array}$ & $\begin{array}{c}\text { Kete } \\
\text { rang } \\
\text { an }\end{array}$ \\
\hline \multirow{2}{*}{$\begin{array}{l}\text { Faktor } \\
\text { Kebudayaan }\end{array}$} & \multirow[t]{2}{*}{$>0,5$} & \multirow[t]{2}{*}{0,789} & 1. Budaya & $>0,5$ & 0,81 & Valid \\
\hline & & & 2. Kelas Sosial & $>0,5$ & 0,84 & Valid \\
\hline \multirow[t]{4}{*}{ Faktor Sosial } & \multirow[t]{4}{*}{$>0,5$} & \multirow[t]{4}{*}{0,755} & $\begin{array}{ll}\text { 3. } & \text { Kelompok } \\
& \text { Referensi }\end{array}$ & $>0,5$ & 0,68 & Valid \\
\hline & & & 4. Keluarga & $>0,5$ & 0,63 & Valid \\
\hline & & & 5. Peran Sosial & $>0,5$ & 0,82 & Valid \\
\hline & & & 6. Status Sosial & $>0,5$ & 0,67 & Valid \\
\hline \multirow[t]{6}{*}{$\begin{array}{l}\text { Faktor } \\
\text { Individu }\end{array}$} & \multirow[t]{6}{*}{$>0,5$} & \multirow[t]{6}{*}{0,751} & 7. Usia & $>0,5$ & 0,49 & $\begin{array}{l}\text { Tidak } \\
\text { Valid }\end{array}$ \\
\hline & & & 8. Pekerjaan & $>0,5$ & 0,41 & $\begin{array}{l}\text { Tidak } \\
\text { Valid }\end{array}$ \\
\hline & & & 9. Keadaan Ekonomi & $>0,5$ & 0,86 & Valid \\
\hline & & & 10. Gaya Hidup & $>0,5$ & 0,67 & Valid \\
\hline & & & 11. Kepribadian Diri & $>0,5$ & 0,90 & Valid \\
\hline & & & 12. Konsep Diri & $>0,5$ & 0,72 & Valid \\
\hline \multirow{4}{*}{$\begin{array}{l}\text { Faktor } \\
\text { Psikologis }\end{array}$} & \multirow[t]{4}{*}{$>0,5$} & \multirow[t]{4}{*}{0,783} & 13. Persepsi & $>0,5$ & 0,70 & Valid \\
\hline & & & 14. Pembelajaran & $>0,5$ & 0,68 & Valid \\
\hline & & & 15. Keyakinan & $>0,5$ & 0,84 & Valid \\
\hline & & & 16. Sikap & $>0,5$ & 0,84 & Valid \\
\hline
\end{tabular}

Hasil uji riset pada kondisi masyarakat indikator pendidikan. Hal ini menunjukan menunjukan bahwa faktor kebudayaan, bahwa usia tidak terlalu mempengaruhi faktor sosial, faktor psikologis, dan faktor motivasi jati diri seseorang untuk individu. Faktor individu terdapat indikator melaksanakan ibadah haji dan umrah. yang tidak valid yaitu indikator usia dan Kondisi saat ini usia tidak menjadi prioritas 
utama dalam melaksanakan ibadah, anakanak muda sangat memiliki motivasi untuk beribadah haji dan umrah berbanding terbalik dengan kondisi yang menjadi fenomena bahwa apabila seseorang ibadah haji dan umrah harus mencapai usia yang matang. Biaya ibadah umrah saat ini cukup terjangkau dan banyak jasa pelayanan travel yang memberikan kemudahan dalam memfasilitasi inadah umrah.

Indikator pada Faktor Individu yaitu pekerjaan, hal ini menunjukan untuk melaksanakan ibadah haji dan umrah tidak hanya orang-orang yang memiliki pekerjaan tetap di perusahaan terkenal atau pegawai negeri sipil. Semua kalangan pekerjaaan dapat melaksanakan ibadah haji dan umrah dengan berbagai latar belakang, bahkan para petanipun saat ini pada saat musim panen mereka banyak melaksanakan ibadah haji dan umrah. Indikator pekerjaan tidak terlalu berpengaruh terhadap motivasi masyarakat untuk melaskanakan ibadah haji dan umrah.

\section{KESIMPULAN DAN SARAN Kesimpulan}

Hasil riset menunjukan faktor-faktor yang mempengaruhi motivasi masyarakat dalam melaksanakan ibadah haji dan umrah yaitu faktor kebudayaan, faktor sosial, faktor psikologis, dan faktor individu akan tetapi indikator usia dan pendidikan tidak dapat menjadi faktor yang signifikan dalam mempengaruhi untuk melaksanakan ibadah haji dan umrah. Fenomena pada masyarakat menunjukan bahwa usia dan pendidikan tidak menjadi faktor yang sangat berpengaruh dalam melaksanakan ibadah haji dan umrah. Hal ini tercermin pada kehidupan masyarakat yaitu kelompok usia muda sudah menjadi tren melaksanakan ibadah umrah dan mengingat waktu tunggu haji yang lama kelompok usia muda sudah banyak yang mendaftarkan untuk melaksanakan ibadah haji. Pergeseran paradigma yaitu dimana dimasyarakat sebelumnya usia untuk melaksanakan ibadah haji dan umrah kecenderungan pada kelompok usia sudah tua dan pekerjaan harus memiliki pekerjaan tetap.

\section{Saran}

Berdasarkan hasil penelitian terdapat beberapa saran yaitu masyarkat sangat awam terhadap rukun ibadah haji dan umrah. Kedua, pemeritnah melalui penyuluh agama pada setiap kantor Kemenag Kabupaten dapat memberikan eduaksi terhadap travel umrah yang resmi dari kemenag karena masih awam terhadap pilihan travel umrah. Ketiga, motivasi dan jati diri masyarakat dalam ibadah umrah harus diedukasi sehingga ketika pulang dari ibadah dapat diterapkan dimasyarakat, dan kelima hasil penelitian ini memiliki keterbatasan sehingga dapat dilakukan penelitian selanjutnya mengenai psikologis dan perlikau ibadah haji dan umrah. 


\section{DAFTAR PUSTAKA}

Abdul Aziz Muhammad Azzam \& Abdul Wahhab Sayyed Hawwas, Fiqh Ibadah,(Jakarta: Sinar Grafika Offset, 2009)

Abu Malik Kamal bin Sayyid Salim, Fiqih Sunah untuk Wanita, (Jakarta: AlPtishom Cahaya Umat, 2007)

Bandalos, D.L. (1993). Factors influencing the cross-validation of confirmatory factor analysis models. Multivariate Behavioral Research, 28(3), 351-374.

Departemen Agama Islam, Pendidikan Agama Islam ,(Jakarta: Departemen Agama, 2001), Cet 9.

Hair, J.F.Jr., Anderson, R.E., Tatham, R.L., \& Black, W.C. (1998), Multivariate Data Analysis $5^{\text {th }}$ Ed., Englewood Cliffs, New Jersey: Prentice Hall.

Kotler, Philip, dan Kevin Lane Keller. 2009. Manajemen Pemasaran, edisi Ketiga Belas, Terjemahan Bob Sabran, MM. Jakarta: Penerbit Erlangga.

Malhotra, N.K. (2004),Marketing Research: An Applied Orientation, New Jersey: Prentice Hall.
Mohaghar, Ali dan Ghasemi, Rohollah. 2011. A Conceptual Model for Cooperate Strategy dan Supply Chain Performance by Structural Equation Modeling a Case Study in the Iranian Automotive Industry, European Journal of Social Sciences - Volume 22

P.Siagian, Sondang, Prof. Dr. MPA.(1988).

Teori dan Praktek Kepemimpinan. Jakarta : Rineka Citra.

Saleb Al-Fauzan, Fiqh sehari-hari, (Jakarta: Gema Insani, 2009) Cet 2.

Sihotang. A. Drs. M.B.A. (2006).Menejemen Sumber Daya Manusia .Jakarta : PT Pradnya Paramita.

Sugiyono. 2005. Metode Penelitian Bisnis, Bandung: PT Alfa Beta

Sunyoto Munandar, Ashar.(2001).Psikologi Industri dan Organisasi.Jakarta: Universitas Indonesia.

Wirawan, Sarlito. (2005).Psikologi Sosial (Psikologi Kelompok dan Psikologi Terapan).Jakarta :Balai Pustaka. 